\title{
Morphological variation of plantain squirrel Callosciurus notatus (Boddaert, 1785) (Rodentia: Sciuridae) populations in West Sumatra, Indonesia
}

\author{
RUHAMA MAYA SARI, DJONG HON TJONG ${ }^{\natural}$, DEWI IMELDA ROESMA \\ Department of Biology, Faculty of Mathematics and Natural Sciences, Universitas Andalas. Jl. Universitas Andalas, Limau Manih, Pauh, Padang 25163, \\ West Sumatra, Indonesia. Tel. +62-751-777427. Fax.+62-751-71343, •email: djonghontjong@ sci.unand.ac.id
}

Manuscript received: 8 January 2020. Revision accepted: 9 June 2020.

\begin{abstract}
Tjong DH, Sari RM, Roesma DI. 2020. Morphological variation of plantain squirrel Callosciurus notatus (Boddaert, 1785) (Rodentia: Sciuridae) populations in West Sumatra, Indonesia. Asian J For 21: 54-60. Plantain squirrel (Callosciurus notatus (Boddaert, 1785)) is unique in terms of morphological and geographical variations, making this species is divided into three sub-species so far. A study about the morphological variation of plantain squirrel among four populations in West Sumatra was conducted. As many as 38 specimens of $C$. notatus were collected from Padang, Lubuk Basung, Sangir, and Baso using a survey and direct collection method. The morphometric measurement was conducted in the Laboratory of Genetic and Biomolecular, Department of Biology, Faculty of Mathematics and Natural Sciences, Andalas University. Morphological measurement data based on 21 external characters and 35 skull characters were analyzed by the Kruskal Wallis test, Principal Component Analysis (PCA), and Unweighted Pair Group Method Arithmetic Average (UPGMA). The result showed that there was morphological variation in ten body characters and nine skull characters. Body and tail length characters that had a relatively longer length ratio were found in Baso population. Character lengths of ears and extremities (ulna and digiti length) which relatively had a longer ratio were found in the Sangir population. Skull morphological characters that showed significant differences were generally found in Baso populations having longer ratio values than other populations. The results of this study suggest that it is necessary to do further research to determine what environmental factors specifically influence certain morphological characters.
\end{abstract}

Keywords: Bukit Barisan Mountain Range, Callosciurus notatus, morphological variation, squirrel

\section{INTRODUCTION}

Callosciurus notatus (Boddaert, 1785) is one of the squirrel species that belong to the subfamily of Sciurinae in the family of Sciuridae (Nowak, 1999). One characteristic that distinguishes this squirrel from other species within the same genus is its habitat which is in the plantations area (Payne et al. 2000). This species is usually found in plantations or secondary forests, particularly living and breeding in monoculture plantations (Francis 2008). C. notatus is a diurnal animal that is active during the day (Saiful and Nordin, 2004).

Callosciurus notatus is geographically distributed in Southeast Asia, including Thailand, Malaysia, Singapore, Sumatra, Java, Borneo, and several smaller surrounding islands (Tamura and Yong 1993). There are two subspecies of this squirrel in Sumatra (i.e., C. notatus vittatus and $C$. notatus tapanulius) and one subspecies each in Java and Kalimantan, namely $C$. notatus notatus and $C$. notatus dulitensis, respectively (Martoyo et al. 2002).

Callosciurus notatus has an average $175-223 \mathrm{~mm}$ in body length, $160-210 \mathrm{~mm}$ tail length, $42-52 \mathrm{~mm}$ hind food length, and 150-280 g body weight (Payne et al. 2000). The specific fur color of this species is brownish agouti on the upper parts and reddish-orange on the underparts that alter from very pale to fairly dark or sometimes with a gray wash. $C$. notatus has distinctive stripes on its flanks with the buff and black line (Francis 2008).

Morphometric studies of intra-specific or inter-specific variations by quantitative analysis are valuable for detecting patterns of geographic variations and delimiting intra-specific or inter-specific evolutionary units ( $\mathrm{Li}$ et al., 2012). For example, Hale and Luz (2003) revealed that there were morphological changes in British red squirrel (Sciurus vulgaris) as a result of introduced species and changes in landscape management. Endo et al. (2004) observed the geographical variations of skull characters among Callosciurus caniceps populations in Thailand and found that the northern population had a larger skull size than the southern population in the continental mainland.

The wide distribution of this species is presumably followed by morphological variation among populations, including the population in West Sumatra. West Sumatra is a region in Sumatra Island crossed by Bukit Barisan mountain range that stretches from north to south of the island with the highest peak of $3.805 \mathrm{~m}$ asl. Anwar et al. (1984) stated that the Bukit Barisan mountain range was formed during the early Paleocene (60 million years ago). The geographical factor variations between the east and the west area sorely affected the ecological condition of each region.

Callosciurus notatus was found in lowland up to 1,500 $\mathrm{m}$ asl (Duckworth et al. 2008). The existence of Bukit Barisan mountain range might act as geographical barrier separating $C$. notatus populations between the western and 
eastern areas. Reece et al. (2011) stated that geographic separation could make the gene pool divergence that interrupts gene flow among the separated populations. Based on such theory, this study aimed to analyze the morphological variations of $C$. notatus from four locations separated by the Bukit Barisan mountain range in West Sumatra.

\section{MATERIALS AND METHODS}

Squirrels were collected from four locations in West Sumatra, Indonesia, i.e.: Padang (9888602 S, 654200 E), Lubuk Basung (9971522 S, 605335 E), Sangir (9827689 S,
749274 E) and Baso (9969295 S, 665103 E) (Figure. 1). Squirrels were captured by using small mammal traps that were placed on the tree branches during the day. Jackfruit, coconut, peanut butter, and rambutan were used as baits. We recorded the age (sub-adult or adult) and the sex of each squirrel captured. A total of 38 specimens (20 males and 18 females) were collected and used for morphological analyses. The number of specimens collected from each location was: Padang (4 males and 3 females), Lubuk Basung (10 males and 7 females), Sangir ( 3 males and 4 females), and Baso ( 3 males and 4 females). The specimens consisted of 30 adults and 8 subadults. Specimens were deposited at the Museum Zoologi Universitas Andalas (MZUA).

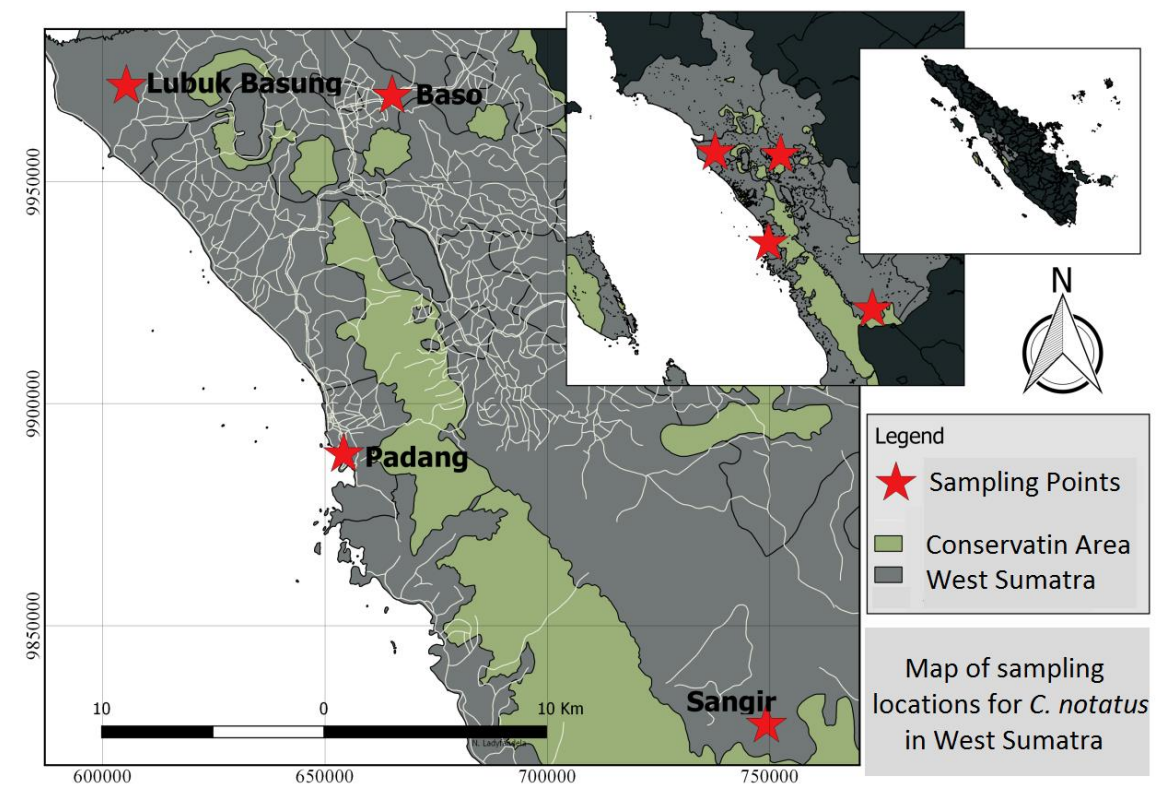

Figure 1. Map of sampling locations for Callosciurus notatus in West Sumatra, Indonesia. Padang and Lubuk Basung represented the western region of Bukit Barisan mountain range, while Baso and Sangir were located in the eastern region.
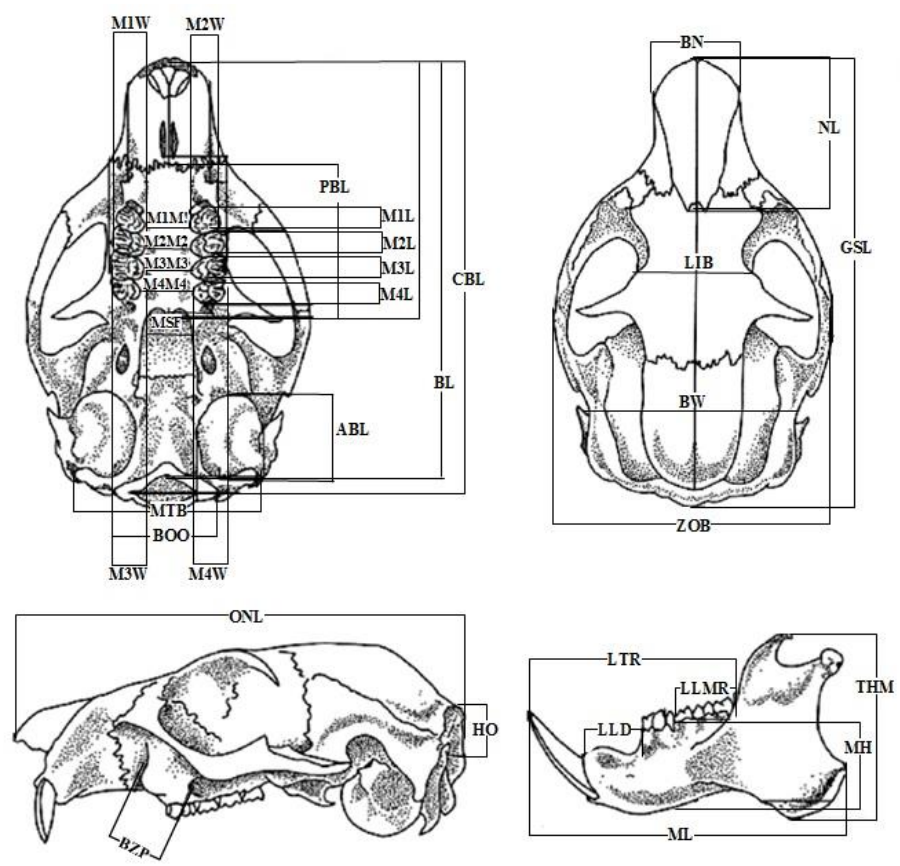

Figure 2. Skull characters measured in this study (sketch modified from Li et al. 2012) 


\section{Procedures}

There were 56 measured characters; i.e. 21 external characters and 35 skull characters. The external characters were measured following Francis (2008) with addition of 17 characters. External characters measurements consisted of head and body length (HB), tail length (T), ear length (E), eye length (EL), interorbital distance (IOD), nose high $(\mathrm{NH})$, nose width (NW), internarial space (IN), ulna length (UL), fore palm length (FP), first finger of forefoot length (1FFL), second finger of forefoot length (2FFL), third finger of forefoot length (3FFL), fourth finger of forefoot length (4FFL), tibia length (TL), hindfoot length (HF), first finger of hindfoot length (1FHL), second finger of hindfoot length (2FHL), third finger of hindfoot length (3FHL), fourth finger of hindfoot length (4FHL) and fifth finger of hindfoot length (5FHL).

Skull characters were measured following Martoyo et al. (2002), Song, Fa-Hong and Xue-Fei (2012), and consisted of maximum length of skull (GLS), nasal length $(\mathrm{NL})$, nasal breadth $(\mathrm{BN})$, zygomatic breadth (ZOB), length of first upper molar (M1L), width of first upper molar (M1W), distance between first upper molar (M1M1), length of second upper molar (M2L), width of second upper molar (M2W), distance between second upper molar (M2M2), length of third upper molar (M3L), width of third upper molar (M3W), distance between third upper molar (M3M3), length of fourth upper molar (M4L), width of fourth upper molar (M4W), distance between fourth upper molar (M4M4), palatal length (PL), length of palatal bridge (PBL), basal length (BL), condylobasal length (CBL), auditory bulla length (ABL), breadth of occipital condyles (BOO), mastoid breadth (MTB), least interorbital breadth (LIB), braincase width (BW), mesopterygoid fossa breadth (MSF), occipito-nasal length (ONL), breadth of zygomatic plate (BZP), height of occipital (HO), mandible length (ML), height of mandible (THM), length of lower diastema (LLD), length of lower molar row (LLMR), length of lower tooth row (LTR), and mandibular height (MH). The diagrammatic description of skull characters is presented in Figure 2.

\section{Data analysis}

The measurement data were divided by head and body length (external measurements) and the maximum length of the skull (skull measurements) to a standardized character size of all specimens. Morphological variations among the population were analyzed using the Kruskal-Wallis test at a significance level of 5\% using SPSS Ver. 17 software. MVSP 3.1 was used to analyze Principal Component Analyses (PCA) and Cluster Analysis.

\section{RESULTS AND DISCUSSION}

Characters comparison among four populations showed significant differences among them in 10 external characters and nine cranial characters (Table 1). KruskalWallis test showed that ten external characters were significantly different among populations. Those characters were head and body length (HB), tail length(T), ear length (E), nose high $(\mathrm{NH})$, nose width (NW), ulna length (UL), first finger of forefoot length (1FFL), second finger of forefoot length (2FFL), third finger of forefoot length (3FFL) and fourth finger of forefoot length (4FFL). Characters on the finger are more differentiated than other characters. The fingers are one part of the squirrel body used to climb. Based on the measurement results, the finger sizes of Sangir population were generally longer than those of Lubuk Basung and Baso populations. The differences were likely affected by the adaptation of $C$. notatus in Sangir that lived in an area large arbor plant as well as being near to the secondary forest whereas $C$. notatus populations founded in Lubuk Basung and Baso were located at the plantation area with palm trees and cacao.

$\mathrm{Li}$ et al. (2012) stated that the phenotype divergence may have regard to the geographical distribution and living conditions, and can serve as a reflection of the adaptation form of the different ecological niches. Hansson and Henttonen (1988) reported that the populations of the same species in different habitats could indicate variations due to the influence of extrinsic factors. One factor that may have significant influence is food. Pizzimenti (1980) stated that there is a relation between diet habits and morphology.

The skull characters that showed variation on the four $C$. notatus populations were the maximum length of the skull (GLS), basal length (BL), condylobasal length (CBL), and mastoid breadth (MTB). These characters affect or are affected by the size of the brain. While the other skull characters with differentiation such as nasal length (NL), length of first upper molar (M1L), mandible length (ML), the height of mandible (THM) and length of lower diastema (LLD) may be more dominated by the type of food. Velhagen and Roth (1997) suggest that the arboreal squirrel usually shows the most substantial mechanical advantage on incisors used to eat fruits and nuts. Hayashida et al. (2007) argued that skull variations of Callosciurus caniceps are influenced by geographical differences.

Based on the analysis of 21 external characters and 35 skull characters, we obtained the Euclidean distance representing relationships based on the similarity of morphological characters among populations (Table 3). According to the Euclidean distances, $C$. notatus populations that have the most similarities were between Padang and Lubuk Basung population, while populations that have the least morphological similarities were between Lubuk Basung and Sangir populations. Based on those values we can infer that geographical distance relatively reflected the relationship distance among populations. Padang population is closer geographically to Lubuk Basung population, while the geographical distance between Lubuk Basung and Sangir is the furthest compared to the other sampling locations. 
Table 1. Comparison of Callosciurus notatus external characters from four populations in West Sumatra, Indonesia by Kruskal-Wallis test that showed significant results.

\begin{tabular}{|c|c|c|c|c|c|}
\hline \multirow[b]{2}{*}{ Characters } & \multicolumn{4}{|c|}{$\begin{array}{r}\text { Population } \\
\end{array}$} & \multirow{2}{*}{$\begin{array}{l}\text { Kruskall- } \\
\text { Wallis Test }\end{array}$} \\
\hline & $\begin{array}{c}\text { Padang } \\
N=6\end{array}$ & $\begin{array}{c}\begin{array}{c}\text { Lubuk Basung } \\
N=16\end{array} \\
\end{array}$ & $\begin{array}{c}\text { Sangir } \\
N=7\end{array}$ & $\begin{array}{l}\text { Baso } \\
\mathrm{N}=7\end{array}$ & \\
\hline \multirow[t]{2}{*}{$\mathrm{HB}$} & $185.0 \pm 9.8$ & $191.1 \pm 7.5$ & $183.7 \pm 8.9$ & $196.9 \pm 3.8$ & $\mathrm{H}=10.372$ \\
\hline & $171.0-195.0$ & $177.0-203.0$ & $172.0-198.0$ & $192.0-203.0$ & $\mathrm{p}=0.016$ \\
\hline \multirow[t]{2}{*}{$\mathrm{T}$} & $183.0 \pm 5.9$ & $182.4 \pm 9.1$ & $192.7 \pm 7.5$ & $204.9 \pm 12.9$ & $\mathrm{H}=14.311$ \\
\hline & $174.0-190.0$ & $165.0-195.0$ & $185.0-203.0$ & $183.0-225.0$ & $\mathrm{p}=0.003$ \\
\hline \multirow[t]{2}{*}{$\mathrm{E}$} & $18.2 \pm 1.2$ & $17.7 \pm 1.2$ & $18.6 \pm 0.9$ & $18.1 \pm 1.3$ & $\mathrm{H}=10.105$ \\
\hline & $17.0-20.0$ & $14.5-20.0$ & $17.0-20.0$ & $16.0-20.0$ & $\mathrm{p}=0.018$ \\
\hline \multirow[t]{2}{*}{ NH } & $7.5 \pm 0.8$ & $6.2 \pm 0.6$ & $6.6 \pm 0.7$ & $6.2 \pm 0.6$ & $\mathrm{H}=14.237$ \\
\hline & $6.6-8.3$ & $5.3-7.2$ & $5.7-7.4$ & $5.6-7.5$ & $\mathrm{p}=0.003$ \\
\hline \multirow[t]{2}{*}{ NW } & $8.4 \pm 0.3$ & $7.9 \pm 0.7$ & $7.6 \pm 0.9$ & $7.8 \pm 0.4$ & $\mathrm{H}=8.784$ \\
\hline & $8.0-8.7$ & $7.0-9.4$ & $6.5-8.8$ & $7.5-8.6$ & $\mathrm{p}=0.032$ \\
\hline \multirow[t]{2}{*}{ UL } & $38.3 \pm 2.3$ & $37.6 \pm 2.0$ & $38.6 \pm 2.3$ & $39.6 \pm 1.6$ & $\mathrm{H}=11.942$ \\
\hline & $36.0-41.0$ & $34.0-41.0$ & $34.5-42.0$ & $37.0-41.0$ & $\mathrm{p}=0.008$ \\
\hline \multirow[t]{2}{*}{$1 \mathrm{FFL}$} & $10.8 \pm 0.7$ & $11.1 \pm 0.6$ & $11.9 \pm 0.6$ & $11.1 \pm 0.9$ & $\mathrm{H}=9.572$ \\
\hline & $10.0-12.0$ & $10.0-12.0$ & $11.0-12.5$ & $10.0-13.0$ & $\mathrm{p}=0.023$ \\
\hline \multirow[t]{2}{*}{$2 \mathrm{FFL}$} & $14.3 \pm 2.3$ & $14.1 \pm 0.7$ & $15.0 \pm 0.6$ & $14.1 \pm 0.1$ & $\mathrm{H}=9.696$ \\
\hline & $12.5-19.0$ & $13.0-15.0$ & $14.0-15.5$ & $12.5-15.5$ & $\mathrm{p}=0.021$ \\
\hline \multirow[t]{2}{*}{ 3FFL } & $15.5 \pm 2.2$ & $15.1 \pm 0.7$ & $15.8 \pm 0.4$ & $15.3 \pm 0.6$ & $\mathrm{H}=10.314$ \\
\hline & $14.0-20.0$ & $14.0-16.5$ & $15.0-16.0$ & $14.5-16.0$ & $\mathrm{p}=0.016$ \\
\hline \multirow[t]{2}{*}{ 4FFL } & $11.7 \pm 0.5$ & $11.7 \pm 0.9$ & $12.2 \pm 1.0$ & $11.8 \pm 0.5$ & $\mathrm{H}=8.989$ \\
\hline & $11.0-12.5$ & $10.5-13.5$ & $11.0-13.5$ & $11.0-12.5$ & $\mathrm{p}=0.029$ \\
\hline
\end{tabular}

Note: The mean, standard deviation, maximum, minimum measurement in millimeters. ( $p$ significance $\leq 0.05 ; \mathrm{N}$ : numbers of specimens)

Table 2. Comparison of Callosciurus notatus skull characters from four populations in West Sumatra, Indonesia by Kruskall-Wallis test that showed significant results

\begin{tabular}{|c|c|c|c|c|c|}
\hline \multirow[b]{2}{*}{ Characters } & \multicolumn{4}{|c|}{ Population } & \multirow[b]{2}{*}{$\begin{array}{c}\text { Kruskal- } \\
\text { Wallis Test }\end{array}$} \\
\hline & $\begin{array}{c}\text { Padang } \\
\mathrm{N}=7\end{array}$ & $\begin{array}{c}\text { Lubuk Basung } \\
\mathrm{N}=17\end{array}$ & $\begin{array}{c}\text { Sangir } \\
N=7\end{array}$ & $\begin{array}{l}\text { Baso } \\
\mathrm{N}=7\end{array}$ & \\
\hline \multirow[t]{2}{*}{ GSL } & $49.4 \pm 1.7$ & $49.4 \pm 1.2$ & $50.1 \pm 1.4$ & $50.9 \pm 1.2$ & $\mathrm{H}=7.908$ \\
\hline & $46.8-52.1$ & $47.4-51.5$ & $48.3-52.6$ & $48.4-51.7$ & $\mathrm{p}=0.048$ \\
\hline \multirow[t]{2}{*}{ NL } & $14.9 \pm 1.0$ & $15.1 \pm 0.7$ & $14.3 \pm 0.6$ & $15.0 \pm 0.5$ & $\mathrm{H}=14.862$ \\
\hline & $13.2-16.3$ & $13.9-16.0$ & $13.2-15.3$ & $14.1-15.4$ & $\mathrm{p}=0.002$ \\
\hline \multirow[t]{2}{*}{ M1L } & $2.0 \pm 0.1$ & $2.0 \pm 0.1$ & $1.9 \pm 0.1$ & $1.9 \pm 0.1$ & $\mathrm{H}=9.001$ \\
\hline & $1.9-2.1$ & $1.8-2.1$ & $1.8-2.1$ & $1.8-2.0$ & $\mathrm{p}=0.029$ \\
\hline \multirow[t]{2}{*}{$\mathrm{BL}$} & $41.9 \pm 1.6$ & $41.9 \pm 1.2$ & $42.3 \pm 1.2$ & $43.7 \pm 0.9$ & $\mathrm{H}=9.119$ \\
\hline & $39.1-44.2$ & $39.9-43.7$ & $41.0-44.4$ & $42.1-44.7$ & $\mathrm{p}=0.028$ \\
\hline \multirow[t]{2}{*}{ CBL } & $44.8 \pm 1.7$ & $44.8 \pm 1.1$ & $45.2 \pm 1.3$ & $46.7 \pm 1.0$ & $\mathrm{H}=10.709$ \\
\hline & $42.0-47.4$ & $42.5-46.4$ & $43.5-47.5$ & $44.5-47.6$ & $\mathrm{p}=0.013$ \\
\hline \multirow[t]{2}{*}{ МTB } & $20.9 \pm 0.4$ & $20.8 \pm 0.6$ & $21.5 \pm 0.6$ & $22.1 \pm 0.3$ & $\mathrm{H}=13.725$ \\
\hline & $20.2-21.4$ & $19.6-21.7$ & $20.4-22.6$ & $21.7-22.7$ & $\mathrm{p}=0.003$ \\
\hline \multirow[t]{2}{*}{ ML } & $32.1 \pm 1.2$ & $32.2 \pm 1.0$ & $32.0 \pm 0.9$ & $33.3 \pm 0.4$ & $\mathrm{H}=9.545$ \\
\hline & 29.9-34.0 & $30.3-33.6$ & $30.6-33.3$ & $32.3-33.6$ & $\mathrm{p}=0.023$ \\
\hline \multirow[t]{2}{*}{ THM } & $15.5 \pm 0.9$ & $15.1 \pm 0.9$ & $15.9 \pm 1.0$ & $16.7 \pm 0.7$ & $\mathrm{H}=9.165$ \\
\hline & $14.3-16.5$ & $13.7-16.8$ & $15.1-18.0$ & $15.8-17.6$ & $\mathrm{p}=0.027$ \\
\hline \multirow[t]{2}{*}{ LLD } & $6.5 \pm 0.4$ & $6.8 \pm 0.3$ & $7.0 \pm 0.5$ & $7.5 \pm 0.2$ & $\mathrm{H}=16.354$ \\
\hline & $5.8-7.1$ & $6.3-7.6$ & $6.4-7.6$ & $7.2-7.8$ & $\mathrm{p}=0.001$ \\
\hline
\end{tabular}

Table 3. The Euclidean distance of Callosciurus notatus

\begin{tabular}{lllll}
\hline Population & Padang & Lubuk Basung & Sangir & Baso \\
\hline Padang & - & & & \\
Lubuk Basung & $\mathbf{8 , 7 5 4}$ & - & - & - \\
Sangir & 10,787 & $\mathbf{1 1 , 2 3 4}$ & 11,160 & - \\
Baso & 10,900 & 10,461 & & \\
\hline
\end{tabular}




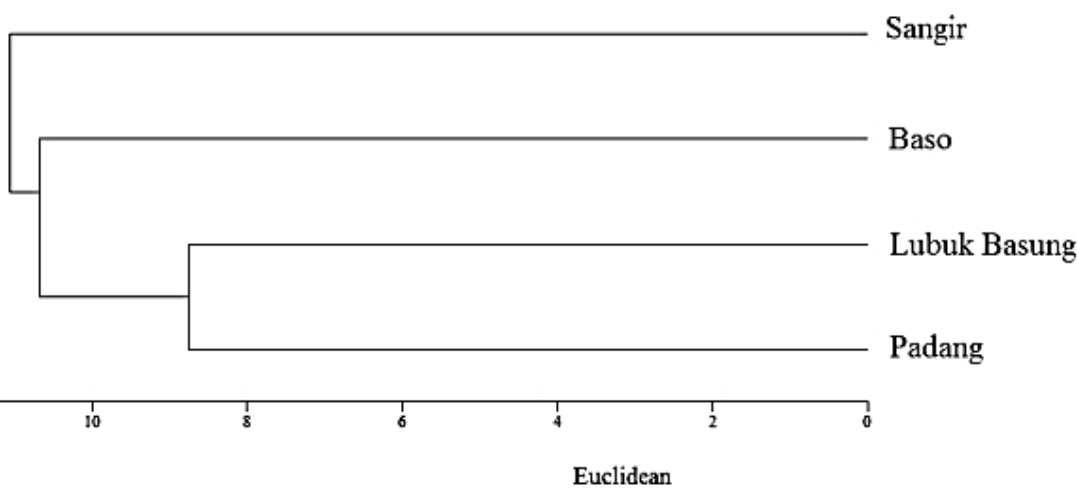

Figure 3. UPGMA phenogram based on morphological characters of Callosciurus notatus

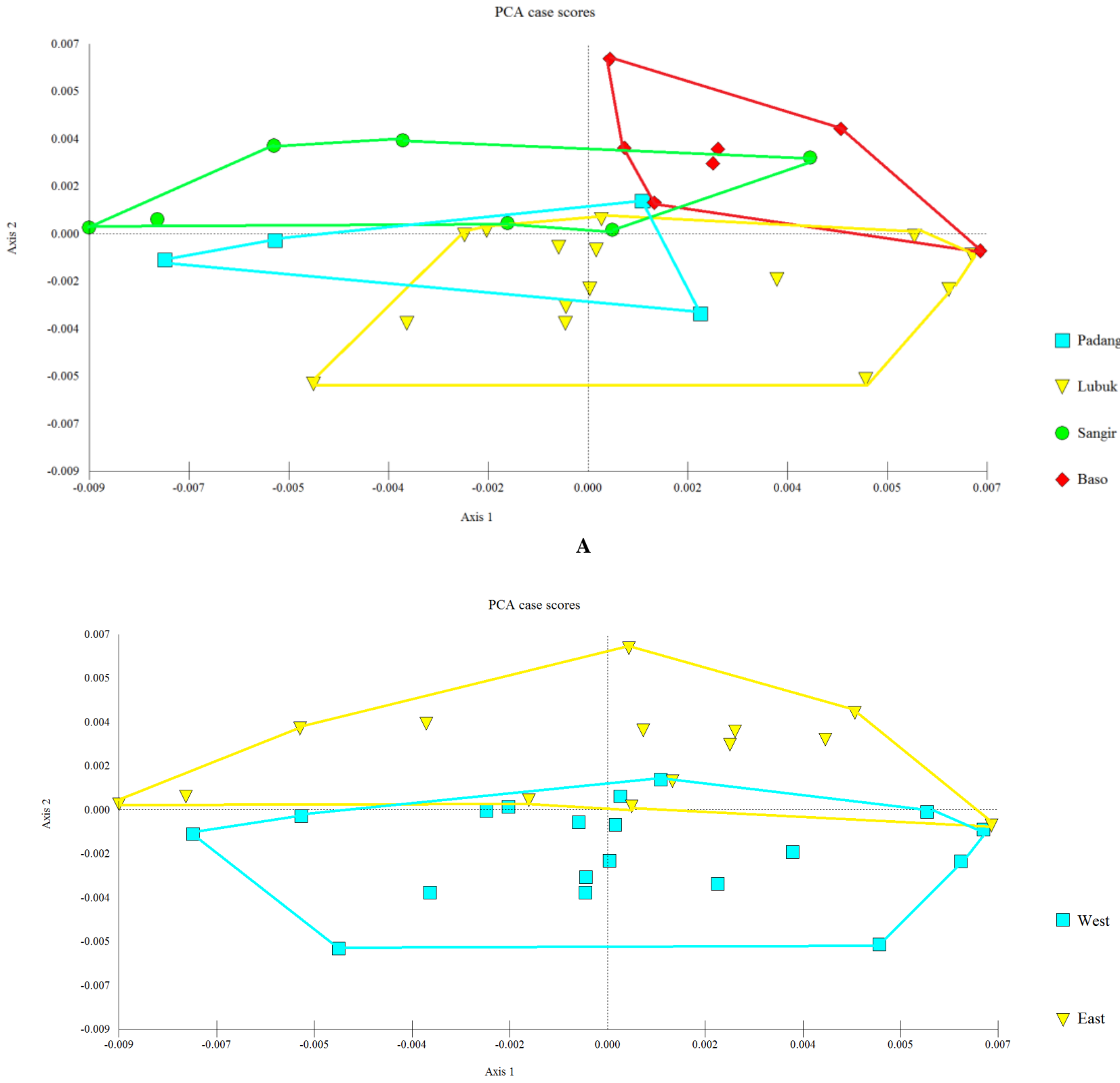

B

Figure 4. The plot of principal component $1(\mathrm{PC} 1)$ versus principal component $2(\mathrm{PC} 2)$ for the Principal Component analysis of Callosciurus notatus group. (A) Based on population group (B) Based on the east and west part of Bukit Barisan mountains range. 
Analysis of UPGMA (Unweighted Pair Group Method Arithmetic Average) showed an overview of phenetics relationships among C. notatus populations (Figure 3). The phenogram (Figure 3) shows that the morphological similarities between populations were relatively related to the geographical distance and geographical location of the sampling sites that were separated by Bukit Barisan mountain range. Map of sampling location (Figure 1) illustrates that Padang is closer geographically to Lubuk Basung. Both locations are also located on the western side of Bukit Barisan. However, C. notatus population from Baso and Sangir tend to have higher Euclidean distances although both locations are on the east side of Bukit Barisan. It is also reinforced by the phenogram which does not show the same cluster between Sangir and Baso. Even C. notatus from Baso has more similarities to Lubuk Basung population that is closer geographically in distance than to Sangir population. Sangir population tends to have more similarities with Padang population that is also closer in geographical distance.

In addition to the geographical distance, the populations of $C$. notatus that were found in similar environmental conditions also showed similarities in morphological characters. Sangir and Padang populations, which are both located in the areas of the fields and adjacent to the secondary forest comparatively had more similarities than Baso, and Lubuk Basung population had. While Baso and Lubuk Basung populations, which are both located on the vast plantations areas, had similarities too. Therefore, the presence of Bukit Barisan mountain range does not entirely affect the similarity or differentiation of morphological characters among populations of $C$. notatus in West Sumatra. There are other factors such as geographical distance and environmental conditions, like available food resources and habitat vegetation, which probably influence the similarity of morphological characters among populations in West Sumatra.

The natural barrier of geographical distance is related to gene flow from separated populations. Andrews (2010) stated that gene flow, genetic drift, and natural selection do not act in isolation in the fragmented habitat. The obstruction of gene flow will result in genetic homogeneity within a metapopulation, promoting the population divergence, and, if continuously, can end up to speciation. Moncried (2015) reported that morphological differentiation in fox squirrels and gray squirrels had been influenced by the lower Mississippi River valley that had been preventing gene flow of these species.

Kramm, Marki, and Glime (1975) reported that morphological characters between populations of red squirrels (Tamiasciurus hudsonicus) in the area of Lake Superior were also influenced by geographical position. The closer geographical distance, the more similarities of morphological characters it had. Barrett and Schluter (2008) stated that the dynamics and different results of adaptation were affected by the variation source. The variations that occur are very related to how the population can respond to environmental change.

The PCA analysis showed the distribution of individuals from each population based on morphology, which is the loading or deciding factor. The ordination of plots (Figure 4) has shown that there are two groupings of C. notatus samples that describe the distribution of populations in the west and east side of Bukit Barisan. Character variation in populations of $C$. notatus in the parts of east and west possibly caused by the difference in environmental conditions that are the result of the formation of the Bukit Barisan since millions of years ago.

Anwar et al. (1984) report that Sumatra that was divided into two sides by the Bukit Barisan has a different ecological condition. The factors such as geomorphology, vegetation, climate, rainfall, and soil variation between the west and east area have impacted the ecology in both separated sites. Colombijn (2005) stated that the Bukit Barisan has two unequal parts that form the narrow coast and the wider half of hills in the west part and alluvial lowland in the opposite part.

$\mathrm{Yu}$ (2002) reported that the morphological and genetic differentiation among some populations of flying squirrels (e.g. Eupetaurus, Eoglaucomys, Hylopetes, and Petaurista) occur in line with the geographical variations along the Trans-Himalaya mountain chain that caused the climate change during the Pleistocene, and also became occurrence of physical barriers to migration. Research by Endo et al. (2003) on the skull variations of Dremomys rufigenis in three geographical locations consisting of Peninsular Malaysia, Viet Nam, Laos and Thailand showed variations affected by the existence of the Isthmus of $\mathrm{Kra}$ as a geographical barrier.

In conclusion, variation of morphological characters of C. notatus in several populations in West Sumatra was found in ten external characters and nine skull characters from a total of 56 characters measured. Body and tail length characters that had a relatively longer length ratio were found in Baso population. Character lengths of ears and extremities (ulna and digiti length) which relatively had a longer ratio were found in the Sangir population. Skull morphological characters that showed significant differences were generally found in Baso populations having longer ratio values than other populations. Based on the results of this study it is hoped that further study will be carried out to determine what environmental factors specifically influence certain morphological characters.

\section{ACKNOWLEDGEMENTS}

We thank Dr. Wilson Novarino, Dr. Rizaldi, Dr. Syaifullah and Dr. Indra Junaidi Zakaria for the valuable suggestion and discussion. We also would like to thank our colleagues who assisted us in the field, Anugerah Viona Agesi, Geneticist Team and Museum Zoology UA Team.

\section{REFERENCES}

Andrews CA. 2010. Natural selection, genetic drift, and gene flow do not act in isolation in natural populations. Nature Educat Knowl 3 (10): 5. Anwar S, Damanik J, Hisyam N, Whitten AJ. 1984. Ekologi Ekosistem Sumatera. Gajah Mada University Press. Yogyakarta. [Indonesian] 
Barrett RDH, Schluter D. 2008. Adaptation from standing genetic variation. Trends in Ecology and Evolution. 23 (1): 38-44. DOI 10.1016/j.tree.2007.09.008

Colombijn F. 2005. A Moving History of Middle Sumatra, 1600-1870. Modern Asian Studies. 39 (1): 1-38. DOI 10.1017/S0026749X04001374

Duckworth JW, Lee, B, Tizard, RJ. 2008. Callosciurus notatus. The IUCN Red List of Threatened Species 2008: e.T3600A9971096. DOI: 10.2305/IUCN.UK.2008.RLTS.T3600A9971096.en

Endo H, J Kimura, T Oshida, B J Stafford, W Rerkamnuaychoke, T Nishida, M Sasaki, A Hayashida, Y Hayashi. 2003. Geographical Variation of Skull Morphology and Its Functional Significances in the Red-Cheeked Squirrel. J Vet Med Sci 65 (11): 1179-1183. DOI: 10.1292/jvms.65.1179

Francis CM. 2008. A Field Guide to The Mammals of Thailand and South-East Asia. Asia Book Co., Ltd. Thailand.

Hale ML, PWW Lurz. 2003. Morphological changes in a British Mamma as a result of introductions and changes in landscape management: the red squirrel (Sciurus vulgaris). J Zool 260 (2): 159-167. DOI $10.1017 /$ S0952836903003595

Hansson L, Henttonen H. 1988. Rodent dynamics as community processes. Tree 3 (8): 195-200. DOI: 10.1016/0169-5347(88)90006-7

Hayashida A, Endo H, Sasaki M, Oshida T, Kimura J, Waengsothorn S Kitamura N, Yamada J. 2007. Geographical variation in skul morphology of gray-bellied squirrel Callosciurus caniceps. J Vet Med Sci 69 (2): 149-157. DOI: 10.1292/jvms.69.149

Kramm KR, Maki DE, Glime JM. 1975. Variation within and among populations of red squirrel in the Lake Superior Region. J Mammal 56 (1): 258-262. DOI: $10.2307 / 1379633$

Li S, Yu FH, Lu XF. 2012. Cranial morphometric study of four giant flying squirrels (Petaurista) (Rodentia: Sciuridae) from China. Zool Res 33 (2): 119-126. DOI: 10.3724/SP.J.1141.2012.02119
Martoyo I, Maharadatunkamsi, Suyanto A. 2002. Morphological variation and status of the plantain squirrel Callosciurus notatus (Boddaert, 1785) in Indonesia. Treubia 32 (1): 39-61. DOI: 10.14203/treubia.v32i1.590

Moncrief ND. 1993. Geographic variation in fox squirrels (Sciurus niger) and gray squirrels ( $S$. carolinensis) of the Lower Mississippi River Valley. J Mammal 74 (3): 547-576. DOI: 10.2307/1382275

Nowak RM. 1999. Mammals of The World, 6th ed Vol II. The John Hopkins University Press, Baltimore.

Payne J, Francis CM, Phillipps K, Kartikasari SN. 2000. Panduan Lapangan Mammalia di Kalimantan, Sabah, Sarawak \& Brunei Darussalam. Prima Centra Indonesia, Jakarta. [Indonesian]

Pizzimenti JJ, RD Salle 1980. Dietary and morphometric variation in some Peruvian rodent communities: the effect of feeding strategy on evolution. Biol J Linnean Soc 13 (4): 263-285. DOI: 10.1111/j.10958312.1980.tb00087.x

Reece JB, LA Urry, MI Cain, SA Wasserman, PV Minorsky, RB Jackson. 2011. Campbell Biology 9th ed. Pearson Education Inc., San Francisco, CA.

Saiful AA, Nordin M. 2004. Diversity and density of diurnal squirrels in a primary hill Dipterocarp forest, Malaysia. J Trop Ecol 20 (1): 45-49. DOI: $10.1017 / \mathrm{S} 0266467404006169$

Tamura N, H Yong. 1993. Vocalizations in response to predators in three species of Malaysian Callosciurus (Sciuridae). J Mammal 74 (3): 703-714. DOI: $10.2307 / 1382292$

Velhagen WA, Roth VL. 1997. Scaling of the mandible in squirrels. J Morphol $232 \quad$ (2): 107-132. DOI: 10.1002/(SICI)10974687(199705)232:2<107::AID-JMOR1>3.0.CO;2-7

Yu F. 2002. Systematics and Biogeography of Flying Squirrels in The Eastern and The Western Trans-Himalayas. [Dissertation]. The University of Florida, Miami, FL. 